\title{
Faktor-Faktor Sosial yang Mempengaruhi Keputusan Pembelian Konsumen Minimarket Indomaret dengan Minimarket Biasa
}

\author{
Muhammad Iqbal Ramadhan ${ }^{1}$, Mohammad Alkadri Perdana ${ }^{2}$ \\ Politeknik Negeri Bengkalis \\ Miqbalramadhan245@gmail.com, perdana@polbeng.ac.id
}

\begin{abstract}
Consumer decisions are processes that occur to consumers when he decides to buy, what to buy, where, when and how to buy it. This study aims to determine the factors that influence consumer decisions in choosing Indomaret minimarkets and ordinary minimarkets and the most dominant factors that influence consumer decisions in choosing the Indomaret minimarket with ordinary minimarkets in the city of Bengkalis. This type of research is observational. This study uses the method of qualitative analysis, quantitative analysis and perception analysis. The results of this study indicate that consumer decisions that are influenced by the social factors of Indomaret minimarket are personality factors with a value of 3.37 and consumer decisions that are influenced by social factors of Indomaret minimarket are reference group factors with a value of 3.49. From the results of the research that has been obtained it turns out that reference groups, family factors, personality factors influence decisions, the most dominant factors are reference group factors and personality factors. While the lowest factor, namely personality factors 2.69 .
\end{abstract}

Keywords: Consumer decisions, indomaret minimarkets With ordinary minimarkets

\section{Pendahuluan}

Perkembangan teknologi dan industri membawa bagi kehidupan manusia terutama dunia usaha pada saat ini. Di samping itu banyaknya usaha yang bermunculan baik perusahaan kecil maupun besar berdampak pada persaingan ketat antar perusahaan baik yang sejenis maupun yang tidak sejenis. Oleh karena itu, pemasaran merupakan salah satu kegiatan yang dilakukan dalam menghadapi persaingan, perkembangan usaha dan untuk mendapatkan laba, sehingga perusahaan dapat mengembangkan produknya, menetapkan harga, mengadakan promosi dan menditribusikan barang dengan efektif.

Pada umumnya perusahaan mengalami kesulitan dalam memonitor, memahami dan menganalisis prilaku konsumen secara tepat dan benar, mengingat banyaknya faktor yang mempengaruhi prilaku kosumen dan adanya perbedaan perilaku untuk masing-masing individu. Dengan demikian perusahaan dituntut untuk dapat memantau perubahan-perubahan perilaku konsumennya, termasuk perilaku konsumen untuk mendapatkan atau memilih produk.

Minimarket Indomaret sebagaimana diketahui adalah salah satu produk yang semakin lama semakin banyak digemari masyarakat karena dalam kemudahan konsumen untuk berbelanja. Demikian juga bagi kalangan masyarakat umum produk di Minimarket Indomaret ini merupakan produk yang biasa dikonsumsi, mudah didapat dan sifatnya tahan lama.

Oleh karena itu, perlu bagi perusahaan untuk menganalisis perilaku konsumen atas perbandingan di Minimarket Indomaret dengan Minimarket biasa 
untuk mengetahui pola perbandingan. Dengan banyaknya Minimarket Indomaret yang ada di pasaran akan mendorong perusahaan bersaing mendapatkan calon konsumen melalui berbagai strategi yang tepat, misalnya mengubah promosi dan harga lebih jauh lagi produsen dalam mendistribusikan produknya ke pasar konsumen berusaha agar Minimarket nya dapat diterima sesuai dengan apa yang diinginkan konsumen. Karakteristik konsumen dalam membandingkan Minimarket Indomaret dengan Minimarket biasa berbeda-beda. Syarat yang harus di penuhi oleh suatu perusahaan agar dapat sukses dalam persaingan adalah berusaha mencapai tujuan untuk menciptakan dan mempertahankan pelanggan dengan membuat citra yang baik di mata pelanggan itu sendiri yang nantinya akan menimbulkan loyalitas yang berkelanjutan.

Hal tersebut bisa dicapai oleh suatu perusahaan melalui upaya menghasilkan dan menyampaikan barang serta jasa yang diinginkan konsumen, dimana kegiatan tersebut sangat tergantung pada perusahaan atau pedagang dengan bermacam atribut melalui harga, produk, pelayanan umum, lokasi dan perilaku konsumen dalam proses pengambilan keputusan untuk membeli berbagai macam pilihan Minimarket yang ada membuat masyarakat memiliki banyak pilihan dalam melakukan kegiatan pembelian barang yang dibutuhkan pada toko pilihannya. Memilih toko adalah proses interaksi antara strategi pemasaran pengecer dan karakteristik individual dan situasional dari pembeli proses ini digambarkan oleh diagram keputusan pembelian pada umumnya. Karakteristik individual seperti gaya hidup menyebabkan pandangan umum tentang aktivitas yang terlibat dalam perilaku berbelanja dan pencarian. Karakteristik pembeli juga mempengaruhi citra toko.

Citra toko pada gilirannya mempengaruhi pilihan toko dan produk akhir atau pembelian merek. Jika pengalaman masalalu memuaskan, maka pilihan akan bersifat kebiasaan. Kecuali jika faktor-faktor lain berubah sejak kunjungan terakhir. Proses pemilihan toko tertentu merupakan fungsi dari karakteristik konsumen dan karakteristik toko. Seperti yang telah diketahui bahwa Minimarket Indomaret Kota Bengkalis dan Minimarket biasa memiliki banyak strategi untuk menarik konsumen. Tetapi mengapa justru masyarakat lebih memilih produk di Minimarket biasa di Kota Bengkalis?

Berdasarkan latar belakang permasalahan di atas dapat ditarik perumusan masalah sebagai berikut: Bagaimana Perbandingan Persepsi apa saja yang mempengaruhi keputusan pemilihan tempat pembelian di Minimarket Indomaret dan Minimarket biasa? Berdasarkan rumusan masalah tersebut maka dapat disusun tujuan dari penelitian ini adalah untuk mengetahui: Untuk mengetahui faktor-faktor sosial yang mempengaruhi keputusan pembelian konsumen pada Minimarket biasa di Kota Bengkalis? Untuk mengetahui bagaimana perbandingan Faktor-faktor Sosial yang Mempengaruhi Keputusan Pembelian Konsumen Minimarket Indomaret dengan Minimarket biasa di Kota Bengkalis?

Hasil penelitian oleh Alavi (2015), judul penelitian Examining shopping mall consumer decision making styles, satisfaction and purchase intention. Permasalahan dalam penelitian ini Memahami gaya pengambilan keputusan konsumen (CDM) adalah penting untuk segmentasi pasar, positioning dan crafting strategi pemasaran dalam pasar. Beberapa penelitian telah diperiksa hubungan struktural di antara gaya pengambilan keputusan itu konsumen pameran selama belanja mall, tingkat kepuasan danniat membeli. Tujuan dari penelitian ini 
adalah untuk menguji CDM gaya sebagai pendahulu dan prediktor tingkat kepuasan danniat membeli. Berdasarkan Inventaris Gaya Konsumen, delapan Gaya CDM yang dipamerkan individu selama kegiatan pusat perbelanjaan diusulkan dalam perspektif utilitarian dan hedonis. Kita menghipotesiskan delapan gaya CDM ini sebagai satu set prediktor pelanggan Kepuasan dan niat membeli. Sebanyak 327 kertas dan kertas yang valid kuesioner dikumpulkan dari beberapa pusat perbelanjaan di Kuala Lumpur, Malaysia. Pemodelan jalur sebagian terkecil (PLS) pendekatan, pemodelan persamaan struktural (PLSSEM) teknik dilakukan untuk menguji hubungan struktural yang diusulkan. Itu penilaian empiris mendukung gaya belanja hedonis konsumen yang menunjukkan tingkat kesadaran yang tinggi, kesadaran merek, consciosness fashion, gaya sadar rekreasi memiliki tingkat yang lebih rendahkepuasan dan niat membeli selama belanja mall sementara konsumen gaya baru dan sadar mode memiliki tingkat yang lebih rendah kepuasan tetapi tidak mengungkap niat pembelian yang lebih rendah. Utilitarian gaya belanja konsumen yang menunjukkan tingkat kesadaran harga tinggi, bingung dengan over choice dan gaya sadar berkualitas tinggi memiliki lebih tinggi tingkat kepuasan sementara pembeli impulsif/ceroboh tidak dan sementara harga sadar, impulsif/ceroboh, bingung dengan over choice konsumen memiliki tingkat niat pembelian yang lebih tinggi tetapi kualitas tinggi konsumen yang sadar tidak mengungkap niat pembelian yang lebih tinggi. Selanjutnya, ada hubungan positif antara kepuasan danniat membeli. Implikasi praktis dan manajerial adalah di diskusikan.

Menurut Helmida (2015) judul penelitian Pengambilan Keputusan Memilih Tempat Belanja di Kec. Tampan Kelurahan Simpang Baru Studi Kasus: Pada Pengunjung Indomaret Kota Pekanbaru, Manusia pada dasarnya adalah kebutuhan, untuk melanjutkan keberlangsungan hidup manusia harus memenuhi kebutuhan hidup, dan semakin banyak kebutuhan seseorang akan semakin bertambah dan bertambah, untuk memenuhi kebutuhan hidup seseorang akan berbelanja sesuai kebutuhan dan dia ingin bertemu kebutuhan pembeli akan memilih atau memutuskan tempat yang menurutnya sesuai untuk memenuhi kebutuhan ini. Keputusan belanja adalah tindakan atau proses memilih pembeli, di mana orang merasa terpenuhi kebutuhan mereka dengan berbelanja di tempat yang lebih baik yang dia lihat yang menyebabkan keputusan untuk membeli tempat tersebut. Oleh karena itu, pembeli akan membandingan antara tempat belanja ke tempat yang menghasilkan kesimpulan bahwa dia pikir dia harus pergi berbelanja. Dengan perkembangan zaman yang serba canggih dan instan ini berbagai perusahaan memanfaatkan perilaku konsumsi manusia sehari-hari yang sedang berkembang serta Indomaret bermerk mini, sebuah fenomena toko modern yang semakin ramai di Indonesia beberapa tahun yang satu ini adalah Indomaret. Minimarket Indomaret adalah formulir penawaran baru yang disediakan oleh perusahaan dalam perdagangan dunia dengan konsep belanja dan kebutuhan di atap, dan melayani belanja bahan makanan dalam bentuk skala. Hingga saat ini kita dapat menemukan di setiap ruang kehadiran miniroad, di samping kebutuhan sehari-hari orang-orang yang menjual produk Indomaret juga mengadakan layanan dan mempekerjakan beberapa, diskon dan promosi menarik masyarakat untuk berkunjung kesana. Sehingga untuk memenuhi kebutuhan konsumen tidak perlu pindah ke toko lain cukup dengan satu cara, yaitu di Indomaret seperti untuk jenis layanan selain dari produk harian yang ditawarkan kepada konsumen adalah 
seperti layanan Indomaret Card, ATM Indomaret, Western Union, Indomaret Delivery, Voucher, Kiosk, Car, Air, Pembayaran Berlangganan, Asuransi Mikro, tiket kereta api, pertunjukan tiket, album CD, Layanan Penjualan Air Galon, dan hand out pulsa Ponsel. Yang mana dari layanan ini tidak dioperasikan pada Indomaret tertentu. Metode yang digunakan adalah metode kuantitatif non inferensial, sedangkan pengumpulan data dilakukan dengan wawancara dan mengirimkan kuesioner kepada konsumen yang menjadi pengunjung Indomaret untuk melihat keputusannya memilih tempat belanja di Indomaret.

\section{Metode Penelitian}

Pada penelitian ini peneliti menggunakan teknik sampling Nonprobality sampling. Nonprobability Sampling adalah teknik pengambilan sampel yang tidak member peluang/kesempatan sama bagi setiap unsure atau anggota populasi untuk dipilih menjadi sampel. Pada penelitian ini peneliti menggunakan cara teknik Purposive sampling. Menurut Sugiyono (2010) Purposive sampling adalah sampel yang dipilih secara cermat dengan mengambil orang atau objek peneliti yang selektif dan mempunya I ciri-ciri yang khusus dari populasi, sehingga dapat dianggap cuku preperensif.

Tujuan sampling ini dapat memudahkan pemilihan criteria khusus agar sampel yang diambil nanti nya sesuai dengan tujuan penelitian dapat memecahkan permasalahan penelitian serta dapat memberikan nilai yang lebih representatif. Adapun karakteristik responden yang akan di jadikan sampel:

1. Berusia di atas 18 tahun

2. Pernah berbelanja di minimarket indomaret dan minimarket biasa

3. Berdomisili di kota Bengkalis

Teknik pengumpulan data merupakan cara-cara yang dilakukan untuk memperoleh data dan keterangan-keterangan yang diperlukan dalam penelitian. Teknik pengumpulan data dalam penelitian ini diharapkan dapat memberikan data yang akurat dan lebih spesifik. Adapun teknik pengumpulan data yang digunakan dalam penelitian ini adalah kuesioner (angket). Kuesioner yaitu teknik pengumpulan data dengan cara menggunakan daftar pernyataan mengenai hal-hal yang berhubungan dengan variabel yang diteliti. Jenis kuesioner yang penulis gunakan adalah kuesioner tertutup, yaitu kuesioner yang sudah disediakan jawaban nya, alasan penulis menggunakan kuesioner tertutup karena kuesioner jenis ini memberikan kemudahan kepada responden dalam memberikan jawaban, kuesione rtertutup lebih praktis, dan dapa tmengimbangi keterbatasan biaya dan waktu penelitian.

Dalam penelitian ini peneliti menggunakan pengukuran skala Likert, yaitu skala yang digunakan untuk mengukur sikap dan pendapat serta persepsi seseorang atau kelompok orang tentang fenomena yang terjadi. Dengan skala Likert, maka variabel yang akan diukur akan dijabarkan menjadi indikator variabel. Kemudian indikator tersebut dijadikan titik tolak untuk menyusun instrument yang dapat berupa pertanyaan atau pernyataan. Untuk memperluas analisis kuantitatif maka jawaban itu akan diberikan skor (nilai) sebagai berikut:

1. Untuk jawaban sangat setuju diberi skor 5

2. Untuk jawaban setuju diberi skor 4

3. Untuk jawaban ragu-ragu diberi skor 3

4. Untuk jawaban tidak setuju diberi skor 2 
5. Untuk jawaban sangat tidak setuju diberi skor 1

Sedangkan nilai (skor) dapat dilihat dengan menghitung nilai terendah $=1$, yaitu jawaban responden adalah "Sangat Rendah", dan nilai tertinggi $=5$, yaitu bila jawaban responden adalah "Sangat Tinggi". Setelah kita mendapatkan data yang kita kumpul kan dari hasil kuesioner (angket), data tersebut masihlah berupa data mentah. Semua data yang diperoleh akan diolah terlebih dahulu dan kemudian disajikan dalam bentuk table serta dianalisa sesuai dengan kode yang diberikan (angket). Tahap-tahap pengelolaan data sebagai berikut yaitu dengan cara memeriksa data yang sudah diolah dan kemudian data tersebut disusun kedalam bentuk table distribusi frekuensi untuk melakukan analisis diskriptif terhadap besarnya tingkat sosial pribadi dan besarnya tingkat keputusan pembeli responden.

Teknik analisis data yang digunakan dalam penelitian ini adalah analisis interaktif. Model iniada 4 komponen analisis yaitu, pengumpulan data, reduksi data, penyajian data, dan penarikan kesimpulan. Menurut Sugiyono (2015) Analisis data adalah proses mencari dan menyusun secara sistematis data yang diperoleh dari observasi, wawancara, catatan lapangan dan dokumentasi dengan cara mengorganisasikan data kedalam kategori, menjabarkan kedalam unit-unit, melakukan sintesa, menyusun kedalam pola, memilih mana yang penting dan mana yang dipelajari, dan membuat kesimpulan sehingga mudah dipahami oleh diri sendiri maupun orang lain.

Indikator-indikator keputusan pembelian pada tahap faktor sosial menurut Kotler dan Amstrong: 1) Kelompok Acuan, 2) Keluarga, 3) Kepribadian. Penjelasan Faktor sosial diantarannya sebagai berikut

a. Kelompok Acuan

Kelompok acuan dalam perilaku pembelian konsumen dapat diartikan sebagai kelompok yang yang dapat memberikan pengaruh secara langsung atau tidak langsung terhadap sikap atau perilaku seseorang tersebut. Kelompok ini biasanya disebut dengan kelompok keanggotaan, yaitu sebuah kelompok yang dapat memberikan pengaruh secara langsung terhadap seseorang. Adapun anggota kelompok ini biasanya merupakan anggota dari kelompok primer seperti keluarga, teman, tetangga dan rekan kerja yang berinteraksi dengan secara langsung dan terus menerus dalam keadaan yang informal. Tidak hanya kelompok primer, kelompok sekunder yang biasanya terdiri dari kelompok keagamaan, profesi dan asosiasi perdagangan juga dapat disebut sebagai kelompok keanggotaan.

b. Keluarga

Dalam sebuah organisasi pembelian konsumen, keluarga dibedakan menjadi dua bagian. Pertama keluarga yang dikenal dengan istilah keluarg orientas. Keluarga jenis ini terdiri dari orang tua dan saudara kandung seseorang yang dapat memberikan orientasi agama, politik dan ekonomi serta ambisi pribadi, harga diri dan cinta. Kedua, keluarga yang terdiri dari pasangan dan jumlah anak yang dimiliki seseorang.

c. Kepribadian

Setiap orang memiliki berbagai macam karakteristik kepribadian yang bebeda-beda yang dapat mempengaruhi aktivitas kegiatan pembeliannya. Kepribadian merupakan ciri bawaan psikologis manusia yang berbeda yang menghasilkan sebuah tanggapan relatif konsiten dan bertahan lama terhadap 
rangsangan lingkungannya. Definisi operasional variabel adalah untuk mengetahui bagaimana mengkur suatu variabel dalam penelitian. Definisi operasional berisikan indikator-indikator dari suatu variabel yang memungkinkan peneliti mengumpulkan data yang relevan untuk variabel tersebut.

\section{Hasil dan Pembahasan}

Penelitian ini dilakukan di Minimarket Indomaret dengan Minimarket biasa di Kota Bengkalis yang akan menganalisa Faktor-faktor Sosial yang Mempengaruhi Keputusan Pembelian Konsumen Minimarket Indomaret dengan Minimarket biasa. Rangkuman Deskriptif Responden Terhadap Faktor-faktor Sosial yang mempengaruhi Keputusan Pembelian Konsumen Minimarket Biasa dan Minimarket Indomaret.

Adapun hasil dari rangkuman variabel Faktor-faktor Sosial yang Mempengaruhi Keputusan Pembelian dapadari variabel keputusan pembelian untuk pernyataan yakni faktor kelompok acuan berpengaruh terhadap faktorfaktor sosial yang mempengaruhi keputusan pembelian, mendapatkan skor mean 2,97 dengan tingkat keterangan sedang, untuk pernyataan kedua yakni faktor keluarga terhadap faktor-faktor sosial yang mempengaruhi keputusan pembelian, mendapatkan skor 3,00 dengan tingkat keterangan sedang, untuk pernyataan ketiga yakni faktor kepribadian terhadapap faktor-faktor sosial yang mempengaruhi keputusan pembelian, mendapatkan skor 3,02 dengan tingkat keterangan sedang, sedangkan untuk minimarket biasa variabel keputusan pembelian untuk pernyataan yakni faktor kelompok acuan berpengaruh terhadap faktor-faktor sosial yang mempengaruhi keputusan pembelian, mendapatkan skor mean 3,33 dengan tingkat keterangan sedang, untuk pernyataan kedua yakni faktor keluarga terhadap faktor-faktor sosial yang mempengaruhi keputusan pembelian, mendapatkan skor 3,12 dengan tingkat keterangan sedang, untuk pernyataan ketiga yakni faktor kepribadian terhadap faktor-faktor sosial yang mempengaruhi keputusan pembelian, mendapatkan skor 3,11 dengan tingkat keterangan sedang.

Dapat dijelaskan bahwa faktor yang paling tinggi nilai mean pada faktorfaktor sosial yang mempengaruhi keputusan pembelian konsumen Minimarket Indomaret adalah faktor kepribadian, dengan nilai mean 3,37 pada sub indikator Membeli produk yang ada di Minimarket Indomaret dan Minimarket biasa karena persepsi terhadap Minimarket ini sangat baik, sedangkan faktor yang paling tinggi nilai mean pada faktor-faktor sosial yang mempengaruhi keputusan pembelian konsumen Minimarket biasa adalah faktor kelompok acuan, dengan nilai mean 3,49 pada sub indikator Tanggapan responden mengenai Membeli dan mengkonsumsi produk yang ada di Minimarket Indomaret dan Minimarket biasa karena lokasi mudah di jangkau.

Faktor yang paling rendah nilai mean pada faktor-faktor sosial yang mempengaruhi keputusan pembelian konsumen Minimarket Indomaret adalah faktor kepribadian, dengan nilai mean 2,69 pada sub indikator Tanggapan responden mengenai Membeli dan mengkonsumsi produk yang ada di Minimarket Indomaret dan Minimarket biasa karena lokasi mudah di jangkau, sedangkan faktor yang paling rendah nilai mean pada faktor-faktor sosial yang mempengaruhi keputusan pembelian konsumen Minimarket biasa adalah faktor kepribadian, dengan nilai mean 3,83 pada sub indikator Tanggapan responden 
mengenai Membeli dan mengkonsumsi produk yang ada di Minimarket Indomaret dan Minimarket biasa karena lokasi mudah di jangkau.

Maka kesimpulannya faktor yang paling tinggi nilai mean pada Minimarket Indomaret adalah faktor kepribadian dengan nilai mean 3,37 pada sub indikator membeli produk yang ada di Minimarket Indomaret dan Minimarket biasa karena persepsi terhadap Minimarket ini sangat baik, sedangkan faktor yang paling tinggi nilai mean pada Minimarket biasa adalah faktor kelompok acuan dengan nilai mean 3,49 pada sub indikator Tanggapan responden mengenai Membeli dan mengkonsumsi produk yang ada di Minimarket Indomaret dan Minimarket biasa karena lokasi mudah di jangkau.

Penelitian ini tidak terlepas dari keterbatasan-keterbatasan yang memerlukan pengembangan penelitian-penelitian selanjutnya. Keterbatasanketerbatasan penelitian ini adalah sebagai berikut: Sampel pada penelitian ini hanya masyarakat umum diKota Bengkalis saja, tidak untuk masyarakat lainnya, jadi hasil penelitian ini tidak bias dijadikan cerminan untuk masyarakat yang lain karena tiap masing-masing individu memiliki karakteristik yang berbeda dalam hal Faktor-faktor Sosial yang Mempengaruhi Keputusan Pembelian Konsumen Minimarket Indomaret dengan Minimarket biasa.

Penelitian ini hanya untuk tahun 2019 saja, sehingga hasil penelitian ini hanya mencerminkan Faktor-faktor Sosial yang Mempengaruhi Keputusan Pembelian Konsumen Minimarket Indomaret dengan Minimarket biasa. Pada penelitian ini indikator dalam faktor-faktor sosial yang mempengaruhi keputusan pembelian konsumen Minimarket Indomaret dengan Minimarket biasa hanya faktor kelompok acuan, keluarga, kepribadian, dan sehingga tidak dapat mencerminkan pengaruh dari variabel lain yang mungkin saja memiliki pengaruh lebih besar terhadap keputusan konsumen.

\section{Kesimpulan dan Saran}

Berdasarkan pembahasan yang telah dikemukakan, dapat diambil kesimpulan sebagai berikut: Faktor-faktor sosial yang mempengaruhi keputusan pembelian konsumen Minimarket Indomaret sesuai dengan penelitian ini dipengaruhi oleh faktor kepribadian, sedangkan Faktor-faktor sosial yang mempengaruhi keputusan pembelian konsumen Minimarket biasa sesuai dengan penelitian ini dipengaruhi oleh faktor kelompok acuan.

Faktor sosial yang paling dominan mempengaruhi keputusan pembelian konsumen Minimarket Indomaret, yaitu faktor kepribadian dengan kategori 3,37 pada sub indikator Membeli produk yang ada di Minimarket Indomaret dan Minimarket biasa karena persepsi terhadap Minimarket ini sangat baik, Sedangkan Faktor sosial yang paling dominan mempengaruhi keputusan pembelian konsumen Minimarket biasa, yaitu faktor kelompok acuan dengan kategori 3,49 pada sub indikator Tanggapan responden mengenai Membeli dan mengkonsumsi produk yang ada di Minimarket Indomaret dan Minimarket biasa karena lokasi mudah di jangkau. Faktor yang paling rendah mempengaruhi keputusan pembelian konsumen Minimarket Indomaret dengan Minimarket biasa, yaitu faktor kepribadian pada sub indikator Tanggapan responden mengenai Membeli dan mengkonsumsi produk yang ada di Minimarket Indomaret dan Minimarket biasa karena lokasi mudah di jangkau. 
Berdasarkan beberapa kesimpulan yang telah dikemukakan sebelumnya, maka dapat diusulkan beberapa saran sebagai berikut: Dari penelitian ini dapat dilihat bahwa faktor-faktor sosial yang mempengaruhi keputusan pembelian konsumen Minimarket Indomaret dengan Minimarket biasa sesuai dengan penelitian ini dipengaruhi oleh faktor kelompok acuan dan kepribadian. Adapun di dalam faktor kelompok acuan, kelompok yang yang dapat memberikan pengaruh secara langsung atau tidak langsung terhadap sikap atau perilaku seseorang tersebut. Kelompok ini biasanya disebut dengan kelompok keanggotaan, yaitu sebuah kelompok yang dapat memberikan pengaruh secara langsung terhadap seseorang. Adapun anggota kelompok ini biasanya merupakan anggota dari kelompok primer seperti keluarga, teman, tetangga dan rekan kerja yang berinteraksi dengan secara langsung dan terus menerus dalam keadaan yang informal. Adapun di dalam faktor kepribadian, Setiap orang memiliki berbagai macam karakteristik kepribadian yang bebeda-beda yang dapat mempengaruhi aktivitas kegiatan pembeliannya. Kepribadian merupakan ciri bawaan psikologis manusia yang berbeda yang menghasilkan sebuah tanggapan relatif konsiten dan bertahan lama terhadap rangsangan lingkungannya.

Dari hasil penelitian menunjukan bahwa faktor yang paling dominan berpengaruh terhadap faktor-faktor sosial yang mempengaruhi keputusan pembelian konsumen Minimarket Indomaret dengan Minimarket biasa adalah faktor sosial pada indikator kelompok acuan dan kepribadian.

\section{Daftar Pustaka}

Alavi. (2015).Examining shopping mall consumer decision-making styles, satisfaction and purchase intention. ISSN: 0959-3969, University of Lethbridge.

Association Marketing American. (2007). Perilaku Konsumen dan Strategi. Pemasaran, Jilid VII, Erlangga, Jakarta.

Engel. (2010). perilaku konsumen. Manajemen Pemasaran. Binarupa Aksara, Jakarta.

Helmida Yanti. (2015). Pengambilan Keputusan Memilih Tempat Belanja Di Kec.Tampan Kelurahan Simpang Baru Studi Kasus: Pada Pengunjung Indomaret Kota Pekanbaru. Jom Fisip Volume 2 No 1, Pekanbaru.

Kotler dan amstrong. (2010). Keputusan pembelian. Prinsip-Prinsip Pemasaran, Jilid 1 dan 2 Edisi Kedua Belas. Erlangga, Jakarta.

Kotler dan Amstrong. (2014). Faktor-faktor keputusan pembelian, manajemen pemasaran, pengertian keputusan pembelian.Jilid 1. Edisi Ketiga Belas. Erlangga, Jakarta.

Kotler dan keller. (2016). Proses-proses keputusan pembelian. Jilid 1. Edisi Ketiga Belas. Erlangga, Jakarta.

Ridwan. (2013). Indentifikasi Skor. Rumus formula lameshow. Cara Menggunakan dan Memaknai Analisis. Alfabeta, Bandung.

Sugiyono. (2010). Teknik pengambilan sampel. Alfabeta, Bandung.

Sugiyono. (2015). Jenis data kualitatif dan data kuantitatif, Data primer dan data skunder, populasi dan sampel, teknik analisis data. Alfabeta, Bandung.

T. Teviana, Riyanti Eva.Vol. X No: (2015). Analisis Perbandingan Persepsi Konsumen Minimarket Indomaret Dengan Alfamafart di Ismaliyah 
Kecamatan Medan Area Kota Medan. Jurnal Plans, penelitian ilmu manajemen dan Bisnis, Medan.

Westwood. (2009). Pengertian pemasaran. How to write marketing plan. PT Elex Media Komputindo, Jakarta 